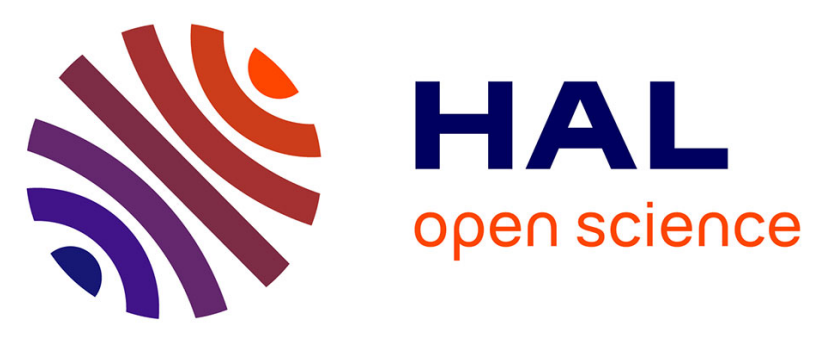

\title{
The role of grain number, nitrogen nutrition and stem number in limiting pea crop (Pisum sativum) yields under agricultural conditions
}

Thierry Doré, Jean-Marc Meynard, Michel M. Sebillotte

\section{To cite this version:}

Thierry Doré, Jean-Marc Meynard, Michel M. Sebillotte. The role of grain number, nitrogen nutrition and stem number in limiting pea crop (Pisum sativum) yields under agricultural conditions. European Journal of Agronomy, 1998, 8 (1-2), pp.29-37. 10.1016/S1161-0301(97)00006-3 . hal-01367935

\section{HAL Id: hal-01367935}

https://hal-agroparistech.archives-ouvertes.fr/hal-01367935

Submitted on 17 Sep 2016

HAL is a multi-disciplinary open access archive for the deposit and dissemination of scientific research documents, whether they are published or not. The documents may come from teaching and research institutions in France or abroad, or from public or private research centers.
L'archive ouverte pluridisciplinaire HAL, est destinée au dépôt et à la diffusion de documents scientifiques de niveau recherche, publiés ou non, émanant des établissements d'enseignement et de recherche français ou étrangers, des laboratoires publics ou privés.

\section{(1) (1) $\$$}

Distributed under a Creative Commons Attribution - NonCommercial - NoDerivatives 44.0 
Final text and figures can be seen on editor site. DOI is $\underline{10.1016 / \mathrm{S} 1161-0301(97) 00006-3}$

The role of grain number, nitrogen nutrition and stem number in limiting pea crop (Pisum sativum) yields under agricultural conditions

T. Doré*, J. M. Meynard and M. Sebillotte ${ }^{1}$

Laboratoire d'Agronomie INRA/INA Paris-Grignon,

16 rue C. Bernard, 75231 Paris Cedex 05, France Phone : 0144081683 / Fax 0144081657 / E-mail : dore@inapg.inra.fr

* To whom correspondence should be addressed.

Short title : Yield variations of the pea crop

Key words : Pisum sativum, yield determinants, on-farm diagnosis, nitrogen nutrition, stem number

1 Present address : INRA, DADP, 147 rue de l'université, 75338 Paris Cedex 07, France 


\begin{abstract}
In a small area of the Paris basin in France, 71 pea (Pisum sativum) crops, cv. Solara, were examined to elucidate the determinants of their yield over three years. The yields ranged from between 3.71 and 7.81 t.ha ${ }^{-1}$, and averaged 5.85, 6.25 and 6.47 t.ha $^{-1}$ in 1988, 1989 and 1990 respectively. The large differences observed each year among fields were related essentially to grain number, whereas mean grain weight was less variable. Grain number and pod number were highly correlated. A substantial effect of nitrogen nutrition, assessed by a Nitrogen Nutrition Index on grain number, was observed. The role of reproductive stem number on grain number was also examined, showing a threshold at 115 stems.m2 below which, in the conditions examined, large grain numbers per stem did not compensate for low stem numbers. Furthermore we have also shown that branching might not be sufficient to compensate for low plant numbers in some crops when nitrogen nutrition is inadequate, and this also leads to a decrease in grain number.
\end{abstract}

\title{
INTRODUCTION
}

The variability in yield of dry peas (Pisum sativum L.) is well-known, but no satisfactory explanations have been found. Numerous authors (see for example Pate, 1975 ; Pate, 1977 ; Dantuma, 1983 ; Davies et al., 1985 ; Heath and Hebblethwaite, 1985) mentioned the existence of "unfavourable factors" in on-farm conditions, which may prevent the potential yield of a variety from being attained. But, unlike vining-peas (Hardwick et al, 1979), no research work has been published that attempts to explain the differences in yield in combining peas. To identify the factors concerning soil, climate and cropping systems which are responsible for differences, it is necessary to understand how yield is determined in farmers crops, i. e. to ascertain which yield components or physiological mechanisms are implicated in yield variations. This agronomic diagnosis of yield development in farmers' crops was first used on wheat crops (Sebillotte et al., 1978) and further extended to other crops and locations (Sebillotte, 1990 ; Meynard and David, 1992). This method is based on surveys on farmers' 
plots ; the use of such surveys to identify reasons for failures to obtain heavy yields has already been used successfully by other authors (Hardwick et al., 1979 ; Boiffin et al., 1981 ; Durrant, 1988 ; Burleigh et al., 1991 ; Shafiq et al., 1993 ; Aubry et al., 1994 ; Leterme et al., 1994). It is the opposite but complementary approach to methods commonly used, which involve a detailed empirical study of the effect of one factor, such as waterlogging (Cannell et al., 1979) or soil compaction (Hebblethwaite and McGowan, 1980) on yield and yield components.

\section{MATERIALS AND METHODS}

The study was designed to determine the role of both the different yield components and nitrogen nutrition in yield variations. Data were collected from 32, 27 and 12 farmers' crops grown in 1988, 1989 and 1990, respectively. All the fields were within an area of c. $1000 \mathrm{~km}^{2}$, representative of the central part of the Paris basin (France) and were chosen to represent the diversity of local cropping systems. The soils were loamy with 13 to $37 \%$ clay, and the main features of the climate over the growing seasons are described in Table 1. There were very few differences in climate between fields in any one year. In each crop on a farmers' field, an area of $c a .500 \mathrm{~m}^{2}$, representative of the crop and well away from the headlands, was selected to carry out all the measures and observations (Boiffin et al., 1981 ; Durrant, 1988). We did not interfere in any way with the choices in crop management decided by the farmers. However the selected crops were sown with cultivar Solara, an "afila" variety (Hedley and Ambrose, 1981).

For each crop, the following data were recorded on six replicates of $c .0 .5 \mathrm{~m}^{2}$ (three or four lines x $0.5 \mathrm{~m}$ ) : number of plants, number of stems at the start of flowering (not available for 1990) and number of reproductive stems (stem carrying at least one grain) at harvest, number of pods (not available for 1990), number of grains per $\mathrm{m}^{2}$, mean grain weight at harvest, and aerial dry matter at the start of flowering All the values of yield and mean grain weight are given with a water content of $0 \%$.

The results of Crozat et al., (1990) were used to assess nitrogen nutrition. Following Greenwood et al. (1990) and Lemaire et al. (1990), these authors established a reference curve for the relationship between aerial dry matter (DM, t.ha $\left.{ }^{-1}\right)$ for Pisum sativum, cv. Solara and 
nitrogen concentration in aerial dry matter $\mathrm{Nc}$, expressed in $\% \mathrm{DM}$, using the equation $\mathrm{Nc}=$ $4.66 \mathrm{DM}^{-0.17}$. The percentage of nitrogen in the pea crop aerial dry matter, Nt, was compared to the reference value, $\mathrm{Nc}$, derived from the reference dilution curve, to give the "N nutrition Index" (NNI) defined as :

$$
\mathrm{NNI}=\mathrm{Nt} / \mathrm{Nc}
$$

According to Lemaire et al., (1989) and Justes et al. (1994), the lower the NNI, the poorer the nitrogen nutrition. We thus compared the nitrogen nutrition of crops with very different amounts of growth. The NNI was measured at the start of flowering. This time, about half way through the growth cycle, is the point when the rate of root elongation declines (Salter and Drew, 1965), and when nodules are almost completely established on the primary (Tricot et al., 1990) and secondary roots.

\section{RESULTS}

Figure 1 gives the distribution of the yields (Y) obtained for the 3 years in the farmers' fields. For 1988 and 1989, we observed rather similar distributions, with a high dispersion around two close mean values (5.85 and 6.25 t.ha ${ }^{-1}$ respectively). In 1990, when we studied fewer fields, the mean value was slightly higher $\left(6.47 \mathrm{t}^{-h a^{-1}}\right)$, and the shape of the histogram somewhat different ; we still observed large differences between fields. Correlations among the following variables - yield (Y), mean grain weight (MGW), grain number $(\mathrm{GN})$, reproductive stem number $(\mathrm{RSN})$, plant number $(\mathrm{PN})$, and NNI - were analysed for all the crops of the 3 years. Pod number (PdN) was not included in this analysis, since values were missing for 1990 . At this scale (Table 2), the highest correlations were between yield, grain number and NNI at the beginning of flowering. The reproductive stem number was rather highly correlated with the nitrogen nutrition index, but not so highly correlated with grain number. The correlations 
between mean grain weight and the other variables were always low, as they were between plant number and the other variables.

Figures 2 and 3 show the relationships between yield and respectively grain number and mean grain weight for each one of the 3 years. In 1988 and 1989, there was a close linear relationship between the yield and the number of grains (Fig. 2). In 1990 the relationship was not so close (Fig. 2), but the correlation between Y and MGW was higher (Fig. 3), due to one crop. Coefficient of variations of GN (respectively 12.0, 13.0, and 6.7\% for 1988, 1989 and 1990) and MGW (respectively 6.7, 3.8, and 7.6\%) were very different, and it was clear that for each year the large differences in yield observed among fields were essentially due to grain number, though this was less marked for 1990. On addition, linear regressions showed that these differences in grain number were correlated to variation in pod number per $\mathrm{m}^{2}$ in 1988 and $1989\left(\mathrm{R}^{2}\right.$ of linear regressions between GN and PdN were respectively 0.89 and 0.87 in 1988 and 1989, $\mathrm{P}<0.001)$. There were few differences in the mean number of grains per pod between fields in each year, and among years.

The crops with poorest nitrogen nutrition always had low GN values (Fig. 4). A significant linear regression was obtained between GN and NNI :

$$
G N=607+1764 N N I\left(P<0.001, R^{2}=0.51\right)
$$

The range in NNI depended on the year : most 1990 crops had an NNI very close to 1, which suggested favourable nitrogen nutrition, whereas several 1988 crops had a small NNI ; 1989 crops were more variable. Due to these differences, a year by year analysis does not make it possible to establish annual relationships, such as for the effect of grain number on yield. The effect of nitrogen nutrition on grain number could be due to an effect of nitrogen on grain number per stem, as shown under experimental conditions by Jeuffroy (1991), Crozat et al. (1994) and Duthion and Sagan (1994). It might also be the result of an effect of nitrogen on stem number.

For a reproductive stem number larger than 115 stems.m² ${ }^{-2}$, there was no GN increase when RSN improved, the largest values being about c. 2800-2900 grains.m-2 (Fig. 5). But for 
values of RSN lower than 115 stems.m-2, none of the fields attained this maximum level. There were large differences among years in the proportions of crops with less than 115 stems.m-2, which were respectively 84,19 , and $8 \%$ in 1988,1989 and 1990 . It seemed that the differences in GN observed were due to (i) differences in the number of reproductive stems, and (ii) differences in the number of grains per stem for a given number of stems.

The reproductive stem number at the start of flowering was greatly dependent on (i) the number of plants and (ii) NNI (Fig. 6). Multilinear regression between RSN on one hand and both the number of plants and the NNI on the other hand showed that a large part of inter-crop differences in stem number. $\mathrm{m}^{-2}$ was thus explained by these two factors :

$$
R S N=-98.8+0.997 P N+131 N N I \text { (multiple } r=0.67, P \leq 0.001 \text { for all coefficients) }
$$

The number of stems at harvest was fairly well correlated with the stem number at the start of flowering (SNSF) $\left(\mathrm{R}^{2}=0.62\right.$ for the crops from 1988 and 1989, $\mathrm{P}<0.01$; data was not available for 1990). This indicates that the main differences observed at harvest already existed at this earlier stage. A similar multilinear regression at the start of flowering gave the following results :

$$
\text { SNSF }=-158.06+1.25 P N+199 N N I \text { (multiple } r=0.75, P<0.001 \text { for all coefficients) }
$$

Less branching was observed for low values of NNI than for high values.

Considering the results shown in Figure 5, the among-crop differences of mean grain number per stem cannot be analysed without reference to stem number. This is why we did not observe directly the effect of nitrogen nutrition on grain number per stem.

\section{DISCUSSION}


When this study was undertaken, it was not known which yield components were responsible for the great variability in pea crop yields within a small geographical area. In the case we studied, differences between plots were very large, far larger than the differences observed between years. It confirmed the high variability of pea crop yields, which has been pointed out by numerous authors to be one of the crop's biggest problems (Snoad, 1983 ; Heath and Hebblethwaite, 1985). During the 3 years of this research, and in particular the first 2 years, grain number was far more important than mean grain weight in explaining yield differences. The limited effect of the end of the pea growth cycle was probably due to favourable growth conditions at late stages, with no constraint from the lack of water in northern areas of France during grain filling, but unfavourable conditions for diseases due to relatively dry weather. These phenomena, widely observed for other grain crops such as wheat or corn in similar areas, may not be as true in drier or in more rainy areas. To improve the stability of pea crop yields requires high grain numbers to be achieved more regularly.

The high correlation which characterised the relationship between grain number and pod number in our results has already been mentioned by other authors (Belford et al., 1980), but is still striking. Pod number per reproductive node is zero, one or two, whereas the maximum grain number per pod, which characterises each variety (Davies et al., 1985), is nine for Solara. According to the hypothesis that all the ovules are fertilised (Linck, 1961), and following the results of Jeuffroy and Chabanet (1994) who showed the major effect of assimilate supply on the regulation of grain number per reproductive node, one might suppose that the opportunity for regulation is greater for grain number per pod than for pod number per node. Nevertheless, Linck (1961) obtained about 35 to $45 \%$ of ovules which became grains in pods (that is to say 3.05 to 4.05 grains per pod for Solara), and we obtained about 3.5 to 4.5 grains per pod, which is a very closed value ; and this stability of mean grain number per pod has often been underlined in experimental conditions (for example French, 1990).

The correlation we observed between NNI and GN may mean that nitrogen nutrition was in some situations a limiting factor for grain number, as it was a limiting factor for growth when NNI values were lower than one. We cannot be sure of this because the grain formation period takes place mostly after the start of flowering, when we measured NNI. Nevertheless, 
the causes of low NNI have been identified elsewhere (Doré, 1992), and it was shown that nitrogen supply probably followed the same pattern for each plot before and after the start of flowering. This effect of nitrogen nutrition on yield determination in pea crops had never been shown before in farmers' conditions in temperate areas, despite the many papers devoted to nitrogen nutrition of peas (see for example the reviews of Pate, 1977 ; Sprent et al., 1988 ; Streeter, 1988 ; Sprent, 1992 ; Doré, 1994a). The result has two important consequences. First, it is important to understand how nitrogen nutrition may become impaired, so that it can be improved where it is responsible for low yields. This is a concern not only for agronomy but also for microbiology, physiology and soil science. Sprent (1992) has shown the effect of the root and nodule environment on nitrogen fixation. In this survey for example, other results (Doré, 1994a) indicated that the major parameter responsible for differences in nitrogen nutrition was nitrogen fixation. These differences were due partly to insect damage by Sitona lineatus L. (Doré and Meynard, 1995) and to seedbed structure. Other factors might be important elsewhere (see the reviews cited above). Second, there is a need to improving knowledge of the physiological mechanisms involved in these effects of nitrogen nutrition.

Our study showed that branching, which is known to compensate for low plant numbers (Hedley and Ambrose, 1981), is not always sufficient on commercial farms to give the maximum grain number. Under our conditions, for Solara, 115 stems. $\mathrm{m}^{-2}$ was a threshold value below which the maximum grain number $c a .2900$ grains. $\mathrm{m}^{-2}$ could not be obtained. The shape of this relationship explains the poor correlation between GN and RSN. These results are very consistent with those of Jeuffroy (1991), who showed, by modelling the formation of grain numbers on a pea stem, that when the number of stems of a crop is low, the growth rate per stem is higher than when there are many stems, and the number of grains per stem is enhanced. Nevertheless at the lowest stem numbers, this effect was not great enough to prevent a decrease in number of grains per $\mathrm{m}^{2}$. The between-year differences in stem number may reflect the differences in climate, sowing date and conditions of crop establishment. But the stem number was not the only yield component responsible for the grain number. This also explains why reproductive stem number was not correlated with grain number in the global analysis : the grain number for two crops with the same stem number may be very different because the grain 
number per stem may be extremely variable, and a plot with fewer than 115 stems. $\mathrm{m}^{-2}$ may have more grains than a plot with a high stem number.

The role of crop establishment in obtaining high yields had already been observed by numerous authors (Meadley and Milbourn, 1970 ; Hedley and Ambrose, 1981, Cousin et al., 1985). Our results showed that branching may compensate for small plant number to some extent only. Studies need to be conducted to understand the origin of low plant numbers and simultaneous low branching in farmers' crops. Some references already exist for plant number, such as those dealing with the effects of diseases (Powell et al., 1984) or climatic conditions (Matthews et al., 1988) or tillage practices (Snobar et al., 1988) on crop establishment. They are far rarer for branching (Doré, 1994b). Besides, the results showed that the better the nitrogen nutrition, the more likely is branching able to compensate for low plant density. This is an indication that the effect of nitrogen nutrition on yield determination starts early in the growth cycle of the pea.

The factors responsible for between-field differences in yield components may vary with geographical area. Nevertheless, the role of grain number, stem number and nitrogen nutrition on pea crop yield determination observed here may have a broad validity in the plains of northern Europe. Our methodology may be of interest in studying the pea crop yield variations in other areas.

\section{ACKNOWLEDGEMENTS}

We wish to thank C Barrier and Y Cariou for technical assistance, the farmers for accepting our presence on their fields, and the Institut National de la Recherche Agronomique and the Union Nationale Interprofessionnelle des plantes riches en Protéines for financial support. 



\section{REFERENCES}

Aubry, C., Latiri-Souki, K., Doré, T. and Griner, C. 1994. Diagnostic des facteurs limitants du rendement du blé dur en parcelles d'agriculteurs dans une petite région du semiaride en Tunisie. agronomie, 14: 213-227.

Belford, R.K., Cannell, R.Q., Thomson, R.J. and Dennis, C.W. 1980. Effects of waterlogging at different stages of development on growth and yield of peas (Pisum sativum L.). J. Sci. Food Agri., 31: 857-869.

Boiffin, J., Caneill, J., Meynard, J.M. and Sebillotte, M. 1981. Elaboration du rendement et fertilisation azotée du blé en Champagne crayeuse. I.- Protocole et méthode d'étude d'un problème technique régional. Agronomie, 1: 549-558.

Burleigh, J.R., Yamoah, C.F., Regas, J.L. and Eylands, V.J. 1991. Analysis of factors related to wheat yield on farm fields in the Bureruka highlands of Rwanda. Agron. J., 83: 625631.

Cannell, R.Q., Gales, K., Snaydon, R.W. and Suhail, B.A. 1979. Effects of short-term waterlogging on the growth and yield of peas (Pisum sativum). Ann. Appl. Biol., 93: 327-335.

Cousin, R., Messager, A. and Vingère, A. 1985. Breeding for yield in combining peas. In: P.D. Hebblethwaite, M.C. Heath and T.C.K. Dawkins (Editors), The Pea Crop: a Basis for Improvement. Butterworths, London, pp 115-129

Crozat, Y., Tricot, F. and Gillet, J.P. 1990. Relationship between dry matter production and $\mathrm{N}$ uptake in pea (Pisum sativum cv. Solara) : a tool for the diagnosis of $\mathrm{N}$ deficiency. In: A. Scaife (Editor), Proceedings of 1st Congress of the European Society of Agronomy. ESA, Colmar.

Crozat, Y., Aveline, A., Coste, F., Gillet, J.P. and Domenach, A.M. 1994. Yield performance and seed production pattern of field-grown pea and soybean in relation to $\mathrm{N}$ nutrition. Eur. J. Agron., 2: 135-144.

Dantuma, G. 1983. Potential and actual yields of dried peas in north western Europe. In: R. Thompson and R. Casey (Editors), Perspectives for Peas and Lupins as Protein Crops. Martinus Nijhof Publishers, The Hague, Boston and London, pp 165-167. 
Davies, D.R., Berry, G.J., Heath, M.C. and Dawkins, T.C.K. 1985. Pea (Pisum sativum L.). In: R.J. Summerfield and E.H. Roberts (Editors), Grain Legume Crops. Collins, London, pp 147-198

Doré, T. 1992. Analyse, par voie d'enquête, de la variabilité des rendements et des effets précédent du pois protéagineux de printemps (Pisum sativum L.). Thèse de Doctorat de l'INAPG, Paris, 214 pp.

Doré, T. 1994a. Influence des stress abiotiques sur le fonctionnement des nodosités de pois. In: B. Ney, E. Duchêne, B. Carrouée and F. Angevin (Editors), Agrophysiologie du Pois Protéagineux. INRA, ITCF, UNIP, Paris, pp 121-128.

Doré, T. 1994b. Influence des stress abiotiques sur l'évolution du nombre de ramifications et de tiges chez le pois. In: B. Ney, E. Duchêne, B. Carrouée and F. Angevin (Editors), Agrophysiologie du Pois Protéagineux. INRA, ITCF, UNIP, Paris, pp 145-155.

Doré, T. and Meynard, J.M. 1995. On-farm approach of attacks by the pea weevil (Sitona lineatus L.; Col., Curculionidae) and the resulting damage to pea (Pisum sativum L.) crops. J. Appl. Ent., 119: 49-54.

Durrant, M.J. 1988. A survey of seedling establishment in sugar-beet crops in 1980 and 1981. Ann. Appl. Biol., 113: 347-355.

Duthion, C. and Sagan, M. 1994. Nutrition azotée et production du pois. In: B. Ney, E. Duchêne, B. Carrouée and F. Angevin (Editors), Agrophysiologie du Pois Protéagineux. INRA, ITCF, UNIP, Paris, pp 179-184.

French, R.J. 1990. The contribution of pod numbers to field pea (Pisum sativum L.) yields in a short growing-season environment. Aust. J. Agric. Res., 41: 853-862.

Greenwood, D.T., Lemaire, G., Gosse, G., Cruz, P., Draycott, A. and Netteson, J.J. 1990. Decline in percentage $\mathrm{N}$ of $\mathrm{C}_{3}$ and $\mathrm{C}_{4}$ crops with increasing plant mass. Ann. Bot., 66: 425-436.

Hardwick, R.C., Andrews, D.J., Hole, C.C. and Salter, P.J. 1979. Variability in number of pods and yield in commercial crops of vining peas (Pisum sativum L.). J. Agric. Sci. Camb., 92: 675-681. 
Heath, M.C. and Hebblethwaite, P.D. 1985. Agronomic problems associated with the pea crop. In: P.D. Hebblethwaite, M.C. Heath and T.C.K. Dawkins (Editors), The Pea Crop: a Basis for Improvement. Butterworths, London, pp 19-29.

Hebblethwaite, P.D. and McGowan, M. 1980. The effects of soil compaction on the emergence, growth and yield of sugar beet and peas. J. Sci. Food Agric., 31: 1131-1142.

Hedley, C.L. and Ambrose, M.J. 1981. Designing "leafless" plants for improving yields of the dried pea crop. Adv. Agron., 34: 225-277.

Jeuffroy, M.H. 1991. Rôle de la vitesse de croissance, de la répartition des assimilats et de la nutrition azotée, dans l'élaboration du nombre de graines du pois protéagineux de printemps (Pisum sativum L.). Thèse de Doctorat, Univ. Paris-Sud, Centre d'Orsay, 206 pp.

Jeuffroy, M.H. and Chabanet, C. 1994. A model to predict seed number per pod from early pod growth rate in pea (Pisum sativum L.). J. Exp. Bot., 45: 709-715.

Justes, E., Mary, B., Meynard, J.M., Machet, J.M. and Thelier-Huche, L. 1994. Determination of a critical nitrogen dilution curve for winter wheat crops. Ann. Bot., 74: 397407.

Lemaire, G., Gastal, F. and Salette, J. 1989. Analysis of the effect of N nutrition on dry matter yield of a sward by reference to potential yield and optimum $\mathrm{N}$ content. In: Proceedings of the 16th International Grassland Congress, Nice, pp 179-180.

Lemaire, G., Gastal, F., Cruz, P. and Greenwood, D.J. 1990. Relationships between plant-N, plant mass and relative growth rate for C3 and C4 crops. In: A. Scaiffe (Editor), Proceedings of 1st Congress of the European Society of Agronomy. ESA, Colmar.

Leterme, P., Manichon, H. and Roger-Estrade, J. 1994. Analyse intégrée des rendements du blé tendre et de leurs causes de variation dans un réseau de parcelles d'agriculteurs du Thymerais. agronomie, 14: 341-361.

Linck, A.J. 1961. The morphological development of the fruit of Pisum sativum, var. Alaska. Phytomorphology, 11: 79-84.

Matthews, S., Abdalla, M.M., Powell, A.A., Walker, K.C. and Zulu, P. 1988. Investigations into ways of improving the establishment of oilseed rape and combining peas. Crop Res. (Hort. Res.), 28: 1-12. 
Meadley, J.T. and Milbourn, G.M. 1970. The growth of vining peas. The effect of density of planting. J. Agric. Sci. Camb., 74: 273-278.

Meynard, J.M. and David, G. 1992. Diagnostic sur l'élaboration du rendement des cultures. Cah. Agric., 1: 9-19.

Pate, J.S. 1975. Pea. In: L.T. Evans (Editor). Crop Physiology : some Case Histories. University Press, Cambridge, pp 191-224.

Pate, J.S. 1977. Nodulation and nitrogen metabolism. In: I.F. Sutcliffe and J.S. Pate (Editors), The Physiology of the Garden Pea. Academic Press, London and New York, pp 349383.

Powell, A.A., Matthews, S, and de Oliveira, M.A. 1984. Seed quality in grain legumes. In: T.H. Coaker (Editor), Advances in Applied Biology, 37, 217-271.

Salter, P.J. and Drew, D.H. 1965. Root growth as a factor in the response of Pisum sativum L. to irrigation. Nature, 206: 1063-1064.

Sebillotte, M. 1990. Some concepts for analysing farming and cropping systems and for understanding their different effects. In: A. Scaiffe (Editor), Proceedings of 1st Congress of the European Society of Agronomy. ESA, Colmar.

Sebillotte, M., Boiffin, J., Caneill, J. and Meynard, J.M. 1978. Sécheresse et fertilisation azotée du blé d'hiver ; essai d'analyse de situations au champ par l'étude des composantes du rendement. Bull. Assoc. Fr. Etude Sol, 3: 197-214.

Shafiq, M., Azeem, M. and Longmire, J. 1993. Diagnosing alternatives in conventional crop rotations : sunflowers as an alternative to wheat in the cotton-based cropping systems of Pakistan's Punjab. Agric. Syst., 42: 245-264.

Snoad, B. 1983. Improving the pea crop. In: R. Thompson and R. Casey (Editors), Perspectives for Peas and Lupins as Protein Crops. Martinus Nijhof Publishers, The Hague, Boston and London, pp 101-111.

Snobar, B.A., Wilkins D.E., Hadjichristodoulou, A. and Haddad, N.I. 1988. Stand establishment in pulse crops. In: R.J. Summerfield (Editor), World Crops: Cool Season Food Legumes. Kluwer Academic Publishers, Dordrecht, pp 257-259 
Sprent, J.I. 1992. Effects of environment on temperate grain legume physiology, with an emphasis on nitrogen fixation.In: Proceedings of the 1st European Conference on Grain Legumes. Angers, pp 131-135

Sprent, J.I., Stephens, J.H. and Rupela, O.P. 1988. Environmental effects on nitrogen fixation. In: R.J. Summerfield (Editor), World Crops: Cool Season Food Legumes. Kluwer Academic Publishers, Dordrecht, pp 801-810.

Conference on Grain Legumes, Angers, pp. 131-135.

Streeter, J. 1988. Inhibition of legume nodule formation and $\mathrm{N}_{2}$ fixation by nitrate. CRC Crit. Rev. Plant Sci., 7: 1-23.

Tricot, F., Crozat, Y., Tardieu, F. and Sebillotte, M. 1990. Establishment and distribution of pea primary root nodules (Pisum sativum L.) as affected by light shading. Symbiosis, 9: 97-103. 
Table 1. Main features of the climate over the 3 years for the period March to July (sowing to harvest) in the studied area. $\mathrm{P}=$ Rainfall $(\mathrm{mm})$; P-ETP $=$ Rainfall minus Evapotranspiration $(\mathrm{mm}) ; \mathrm{T}=$ mean temperature $\left({ }^{\circ} \mathrm{C}\right)$

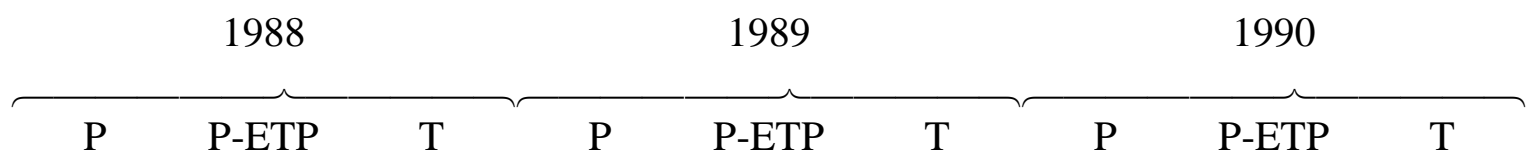

$\begin{array}{cccccccccc}\text { March } & 102.6 & -32.0 & 6.7 & 51.4 & -6.5 & 9.4 & 10.6 & 33.4 & 8.1 \\ \text { April } & 16.2 & 64.4 & 9.8 & 94.6 & 57.3 & 7.6 & 54.6 & 17.4 & 8.6 \\ \text { May } & 144 & -51.9 & 14.2 & 20.8 & 116.9 & 14.7 & 14.0 & 113.1 & 14.8 \\ \text { June } & 25.9 & 91.5 & 15.5 & 93.8 & 20.2 & 15.0 & 66.6 & 34.8 & 15.2 \\ \text { July } & 85.2 & 10.5 & 16.7 & 23.3 & 121 & 18.3 & 33.0 & 137.4 & 17.8\end{array}$


Table 2. General correlations (analysis over 3 years, 71 crops) between yield components and yield (see text for abbreviations)

Yield Grain Number Mean Grain Plant Number Reproductive Weight

Stem Number

Grain Number $\quad 0.881$

Mean Grain
Weight

0.296

$-0.184$

Plant Number

0.223

0.328

$-0.243$

Reproductive

0.461

0.468

$-0.004$

0.543

Stem Number

Nitrogen

0.716

0.721

0.017

0.362

0.579

Nutrition Index 
Fig. 1. Distribution of grain yields for the survey's crops throughout the three years.

Fig. 2. Relationships between grain number and yield for $1988(\bullet) ; 1989(\bullet)$; and $1990(\square)$.

Fig. 3. Relationships between mean grain weight and yield for $1988(\diamond) ; 1989(\bullet)$; and 1990 $(\square)$.

Fig. 4. Relationships between nitrogen nutrition index and grain number for $1988(\diamond)$; 1989 (•); and $1990(\square)$.

Fig. 5. Relationships between the reproductive stem number and grain number for $1988(\diamond)$; 1989 (•) ; and $1990(\square)$.

Fig. 6. Relationships between plant number and reproductive stem number for the 3 years, according to NNI values : NNI $\leq 1(\bullet)$; or NNI $>1(\square)$. 
